\title{
Analysis of Students' Mathematical Communication Ability in the Application of Vygotsky's Theory at High School Level
}

\author{
Muhammad Ishak Sinaga ${ }^{1}$, Bornok Sinaga ${ }^{2}$, Elvis Napitupulu ${ }^{3}$ \\ ${ }^{1,2,3}$ Universitas Negeri Medan, Indonesia \\ shaqnaga67@gmail.com,bsinaga@unimed.ac.id,elvisnapit@gmail.com
}

\begin{abstract}
This study aims to analyze and discover the extent to which students 'mathematical communication skills in the application of Vygotsky's theory, to analyze and find descriptions of students' answer processes through tests of mathematical communication skills, and to analyze and find errors and difficulties of students in developing mathematical communication skills. Data obtained through tests of mathematical communication skills, Vygotsky's Theory questionnaire, student response questionnaires, interview guidelines, and data triangulation. This study uses qualitative data analysis used to analyze data on students' mathematical communication skills and student response questionnaire data through learning in the application of Vygotsky's theory with 5 items of two-variable linear program material in the form of essays in grade XI MIA-2 students of Al Ulum Medan Private High School. Who are given treatment through learning by applying Vygotsky's theory in the odd semester of the 2019/2020 learning year, which has 35 students. Based on the research results, there were 3 students (8.57\%) who had a high level of mathematical communication skills; 7 students (20\%) have moderate level of mathematical communication skills; 25 students (71.43\%) have a low level of mathematical communication skills. After analyzing the student's answer process descriptively, the student's answer process to the mathematical communication test can be concluded that in the first indicator there are 15 students who are able to solve the questions correctly. In the second indicator, there are 8 students who are able to solve the questions correctly. In the third indicator, there are 8 students who are able to solve the questions correctly. In the fourth indicator, there are 4 students who are able to solve the questions correctly. In the fifth indicator, there are 6 students who are able to solve the questions correctly. In the sixth indicator, there are 4 students who are able to solve the questions correctly.
\end{abstract}

\section{Introduction}

One of the subjects in school that can invite students to sharpen their brains is mathematics. Mathematics is a science that has special characteristics, one of which is deductive reasoning in mathematics with regard to abstract and hierarchically arranged ideas, concepts, and symbols, so that mathematics education and teaching need to be handled in a hierarchical manner special anyway. Through this special treatment, it is hoped that the next generation will be able to master mathematics well and in the end can apply mathematics in everyday life. Not only memorizing mathematical formulas, students must also be able to use mathematics to solve problems around their lives. The 
presentation of problems related to everyday life in mathematics will lead students to understand the benefits of the knowledge they learn. Problems related to everyday life (contextual problems) can be presented in the form of story problems where at the end of each subject of mathematics, the story problem is something that is never left behind.

The development of Science and Technology (IPTEK) nowadays has made it easier for humans to communicate and obtain various information quickly from all corners of the world. However, on the other hand, understanding the development of science and technology requires a qualified understanding so that the information obtained can be selected according to the prevailing culture in society. Therefore, human resources (HR) who have the ability to think at a high level (high order thinking) are needed in terms of thinking logically, critically, creatively and able to work together proactively. To support this ability, it can be developed in mathematics learning.

To anticipate the advancement of science and technology, it is necessary to reform the learning process in the classroom. The task and role of the teacher is no longer just a provider of information (transfer of knowledge), but as a stimulant for students to learn (stimulation of learning) so that they can construct their own knowledge through various problem solving, reasoning and communication activities (doing math) as a means of training for critical thinking. and creative.

Through good mathematics education, students can indeed obtain various kinds of provisions in facing challenges in the global era. In the 2013 curriculum itself, the use of technology in learning became something that was highly recommended. The learning process in the 2013 curriculum requires students to participate actively and provide sufficient space for students' creativity, interests, and talents (Fitri, Syahputra, \& Syahputra, 2019).

Baroody (Ansari, 2016) states that there are two important reasons why mathematical communication needs to be developed among students. First, mathematics is language; meaning that mathematics is not just a tool to aid thinking (a tool to aid thinking), a tool for finding patterns, solving problems or drawing conclusions, but mathematics is also a valuable tool for communicating various ideas clearly, precisely and accurately. Second, mathematics learning as social activity; meaning as a social activity in learning mathematics, mathematics is also a vehicle for interaction between students, and also the interaction between teachers and students. This is the most important part in accelerating students' understanding of mathematics. In addition, the interactions formed in the learning process can also improve students' mathematical communication skills.

The Indonesian government has made various efforts to improve the quality of teaching and improve student mathematics learning outcomes, because mathematics is a very important science in every level of education pursued by every Indonesian citizen. The government's efforts include developing curricula, providing training to teachers, completing educational infrastructure and even improving teacher welfare. Along with the development of the internet, learning strategies have shifted and various information and communication technology-based learning strategies have emerged, from e-learning models, smart classroom technology, virtual classrooms, belded learning, etc. (Fitri \& Zahari, 2019).

The effectiveness of the teacher in teaching can be seen from how the teacher conveys knowledge to students. This is in line with Babar's opinion (Sari, 2017), namely "If a mathematics teacher has knowledge of the subject matter and does not know how to effectively transfer knowledge to students, then they cannot teach mathematics effectively." 


\section{Review of Literatures}

According to Irhamna (2020) mathematics is a universal science. Mathematics is also seen as the queen of science. To be able to teach mathematics, a teacher must be able to prepare lesson plans so mathematics lessonscan be received by students (Nasution, 2020). One alternative learning technique that can be used in mathematics learning is scaffolding technique. This technique encourages students to learn through their own active involvement. However, in the learning process students get help or guidance from the teacher so that they are more focused so that the learning implementation process and the goals to be achieved are carried out well.

In learning the application of Vygotsky's theory, it is necessary to pay attention to three important aspects, namely the Zone of Proximal Development/ZPD or the Zone of Proximal Development, Scaffolding and language and thinking. First, the Proximal Development Zone is a gap between actual development and potential development, meaning that it is the gap between whether a child can do something independently and whether a child can do something under adult direction or in cooperation with peers. The purpose of ZPD is that ZPD focuses on social interaction which will facilitate children's development.

Second, scaffolding learning can be interpreted as a technique of providing structured learning support, which is carried out at an early stage to encourage students to learn independently. The provision of learning support is not carried out continuously, but along with the increase in student abilities, gradually the teacher must reduce and release students to learn independently. If students have not been able to achieve independence in their learning, the teacher returns to the support system to help students make progress until they are truly able to achieve independence. The scaffolding given by the teacher is in the form of giving directions or procedures in solving difficulties faced by students in working individually or in groups.

Third, the use of language in the learning process emphasizes that a child's form of statement is an important part and acts as a real action in achieving the expected goals. Children don't just talk about what they do. The statements and actions they take are part of a psychological function that is complex and unified, which leads to problem solving of the problems it faces.

However, in reality, the application of Vygotsky's theory in mathematics learning has not been very visible, especially in the application of three important aspects of the theory. In general, teachers still use conventional learning which tends to be more "teacher oriented". This is in line with Sinaga's (2012) statement which states that the application of conventional learning by teachers so far has not fully achieved the desired learning completeness for all students. This is due to the perception of students' conventional learning only being passive and only receiving input in the form of knowledge from the teacher. This is what can cause students to be less able to reason logically and communicate mathematical concepts well. As a result, students tend to be less independent in solving the math problems they face.

Scaffolding, which is expected to lead students to their zone of proximal development, has not worked properly. This is in line with Sari's (2017) opinion which explains that there are several causes for low student learning outcomes, including the ineffective use of techniques by the teacher, students do not pay attention to the teacher explaining the subjects conveyed, when learning takes place it appears that the teacher at the beginning of learning does not make apperceptions., the teacher immediately wrote the material on the blackboard, then students were asked to take notes, after finishing the 
teacher immediately read the material on the blackboard. When the teacher reads the material, many students do not pay attention and even some students are asleep.

\section{Research Methods}

The subjects in this study were students of grade XI MIA-2 at Al Ulum Medan Private High School who were treated through learning by applying Vygotsky's theory in the odd semester of the 2019/2020 learning year, with 35 students. The object of this research is the mathematical communication skills in the application of Vygotsky's theory on the subject of two-variable linear programming. The object of this research, among others, is that it can be seen from the test results of students' mathematical communication skills, namely through student answer sheets, the effectiveness of Vygotsky's theory can be seen from questionnaires, and through interviews, namely transcripts of tape-recorder recordings to students and interviews with teachers. This research is categorized into a qualitative descriptive research type which is the research instrument of the researcher himself. In other words, the main instrument in this study is the researcher himself, which means that the position of the researcher is the key (determinant) in filtering and analyzing data. In addition to researchers as the main instrument in research, simple instruments were developed to sharpen and complement the research data. These instruments include: tests of mathematical communication skills, Vygotsky's Theory questionnaire, student response questionnaires, interview guidelines, and data triangulation. The data collected in this research is descriptive, namely an actual explanation of the level of mathematical communication skills in the application of Vygotsky's theory.

\section{Discussion}

The description of students 'mathematical communication skills was obtained based on the scores of each student from the results of the students' mathematical communication tests. For that all student answer sheets from the results of students' mathematical communication tests are collected for examination and given a score. The scoring for each student's answer is based on the scoring guideline for mathematical communication, then the total score of each student is found. To find out the level, it will be categorized based on the scoring category.

The students' mathematical communication test consists of 4 questions in the form of descriptions with linear program material. From the results of the validation and testing of the instrument, it was found that the 4 questions could be used with a little revision, were valid and reliable in the very high category. The mathematics communication skills test was held on Friday, 27 July 2018 for 80 minutes. Mathematical communication tests are carried out by students individually and honestly and are directly supervised by researchers and teachers of mathematics subjects at SMA Al Ulum Medan. The level of student mathematical communication can be seen in Table 1 below.

Table 1. Students' Mathematical Communication Ability Levels

\begin{tabular}{|c|c|c|c|}
\hline Value Interval & The Number Of Students & Percentage & Assessment criteria \\
\hline $0 \leq \mathrm{SKKM} \leq 74$ & 25 & $71,43 \%$ & Low \\
\hline $75 \leq \mathrm{SKKM} \leq 84$ & 7 & $20 \%$ & Medium \\
\hline $85 \leq \mathrm{SKKM} \leq 100$ & 3 & $8,57 \%$ & High \\
\hline
\end{tabular}

Information: SKKM = Score of Mathematical Communication Ability 
The data above shows that as many as 3 students (8.57\%) have a high level of mathematical communication skills of all students who took the mathematics communication ability test after learning the two-variable linear program was completed. A total of 7 students (20\%) had a medium level of mathematical communication skills, while 25 students $(71.43 \%)$ had a low level of mathematical communication skills. This data was obtained after the researcher examined the answer sheets of all students and gave an assessment based on the predetermined assessment criteria for each test question.

Based on the results of the students 'mathematical communication skills test, which had been corrected according to the scoring guidelines for the students' mathematical communication skills test that had been designed, 6 out of 36 students were selected as research subjects who were subjected to interviews according to the indicators previously described. The research subjects who were subjected to interviews are as follows:

Table 2. Research Subjects Selected for Interviewing Students' Mathematical Communication Skills

\begin{tabular}{|c|l|l|l|}
\hline No & $\begin{array}{c}\text { Student } \\
\text { Code }\end{array}$ & Score Category & \multicolumn{1}{|c|}{$\begin{array}{c}\text { Ans wer } \\
\text { Criteria }\end{array}$} \\
\hline 1 & S-15 & High Ability & - \\
\hline 2 & S-16 & Medium Ability & - \\
\hline 3 & S-09 & Low Ability & - \\
\hline 4 & S-17 & Low Ability & Almost True \\
\hline 5 & S-21 & Low Ability & Many Mistakes \\
\hline 6 & S-13 & Low Ability & Special Cases \\
\hline
\end{tabular}

Some of the research findings are based on the results of research data analysis of students' mathematical communication skills in learning in the application of Vygotsky's theory in the classroom. The findings of this study are described by taking into account the criteria for interview subjects which are grouped into six categories, namely: (1) high; (2) moderate; (3) low; (4) almost correct; (5) much wrong; and (6) special cases.

\subsection{Research Findings of Mathematical Communication Ability in Students with High Abilities}

The following are the findings of research on students' mathematical communication skills with the criteria of students with high abilities in table 3 below.

Table 3. Summary of Research Findings of Mathematical Communication Ability Students with High Abilities

\begin{tabular}{|c|c|c|}
\hline No. & $\begin{array}{l}\text { Mathematical Communication } \\
\text { Ability Indicator }\end{array}$ & Research Findings \\
\hline 1 & $\begin{array}{l}\text { Using models, diagrams and symbols } \\
\text { to represent a mathematical concept or } \\
\text { idea }\end{array}$ & $\begin{array}{l}\text { Students have been able to represent the probl em } \\
\text { in the form of a relatively long story problem into } \\
\text { symbols and mathematical models that are } \\
\text { correct in writing, but } S-15 \text { has difficulty when } \\
\text { asked to explain the steps to make a mathematical } \\
\text { model of the problem of the story problem that is } \\
\text { given verbally. }\end{array}$ \\
\hline 2 & $\begin{array}{l}\text { Present oral, written, picture and } \\
\text { diagram math statements }\end{array}$ & $\begin{array}{l}\text { Students are able to explain the idea contained } \\
\text { in the story problem in their own words and } \\
\text { explain the idea in writing. } \\
\text { Students are able to make drawings that ar } \\
\text { relevant to the correct mathematical model. }\end{array}$ \\
\hline 3 & Perform mathematical manipulations & $\begin{array}{l}\text { Students are able to solve math problems using } \\
\text { the right method or method. }\end{array}$ \\
\hline 4 & $\begin{array}{l}\text { Find patterns or properties of } \\
\text { mathematical phenomena to make } \\
\text { generalizations }\end{array}$ & $\begin{array}{l}\text { Students are able to find several poss ible patterns } \\
\text { of the optimum value of the known optimum } \\
\text { function. }\end{array}$ \\
\hline 5 & Checks the validity of an argument & $\begin{array}{l}\text { Students are able to make correct decis ions based } \\
\text { on the patterns obtained. }\end{array}$ \\
\hline 6 & $\begin{array}{l}\text { Draw conclusions, compile evidence, } \\
\text { provide reasons or evidence for several } \\
\text { solutions }\end{array}$ & $\begin{array}{l}\text { Students are not able to make conclusions in their } \\
\text { own written language. }\end{array}$ \\
\hline
\end{tabular}




\subsection{Research Findings of Mathematical Communication Ability in Students with}

Moderate Ability

The following are the findings of research on students' mathematical communication skills with the criteria of students with moderate abilities in table 4 below.

Table 4. Summary of Research Findings of Students' Mathematical Communication Ability with Moderate Ability

\begin{tabular}{|c|c|c|}
\hline No. & $\begin{array}{c}\text { Mathematical Communication } \\
\text { Ability Indicator }\end{array}$ & Research Findings \\
\hline 1 & $\begin{array}{l}\text { Using models, diagrams and symbols } \\
\text { to represent a mathematical concept or } \\
\text { idea }\end{array}$ & $\begin{array}{l}\text { Students are able to represent the problem in the } \\
\text { form of a relatively long story question into the } \\
\text { correct symbols. However, when creating a } \\
\text { mathematical model students have difficulty } \\
\text { determining the appropriate sign of inequality to } \\
\text { represent the maximum or minimum constraints. }\end{array}$ \\
\hline 2 & $\begin{array}{l}\text { Present oral, written, picture and } \\
\text { diagram math statements }\end{array}$ & $\begin{array}{l}\text { Students have a little difficulty in explaining } \\
\text { the ideas contained in the story problem in } \\
\text { their own words and explaining the idea in } \\
\text { writing. } \\
\text { Students also experience difficulties in making } \\
\text { relevant drawings according to the correct } \\
\text { mathematical model. }\end{array}$ \\
\hline 3 & Perform mathematical manipulations & $\begin{array}{l}\text { Students are able to solve math problems using } \\
\text { the right method or method. }\end{array}$ \\
\hline 4 & $\begin{array}{l}\text { Find patterns or properties of } \\
\text { mathematical phenomena to make } \\
\text { generalizations }\end{array}$ & $\begin{array}{l}\text { Students have a little difficulty finding several } \\
\text { possible patterns of the optimum value of the } \\
\text { known optimum function. }\end{array}$ \\
\hline 5 & Checks the validity of an argument & $\begin{array}{l}\text { Students have little difficulty making correct } \\
\text { decisions based on the patterns obtained }\end{array}$ \\
\hline 6 & $\begin{array}{l}\text { Draw conclusions, compile evidence, } \\
\text { provide reasons or evidence for several } \\
\text { solutions }\end{array}$ & $\begin{array}{l}\text { Students have a little difficulty making } \\
\text { conclusions in their own written language }\end{array}$ \\
\hline
\end{tabular}

\subsection{Research Findings of Mathematical Communication Ability in Students with Low} Ability

The following are the findings of research on students' mathematical communication skills with the criteria of students with low abilities in table 5 below.

Table 5. Summary of Research Findings of Students with Low Ability Mathematical Communication Ability

\begin{tabular}{|l|l|l|}
\hline No. & $\begin{array}{c}\text { Indikator Kemampuan Komunikasi } \\
\text { Matematik }\end{array}$ & \multicolumn{1}{|c|}{ Temuan Penelitian } \\
\hline 1 & $\begin{array}{l}\text { Using models, diagrams and symbols } \\
\text { to represent a mathematical concept or } \\
\text { idea }\end{array}$ & $\begin{array}{l}\text { Students are not able to represent the problem in } \\
\text { the form of a relatively long story problem into } \\
\text { the correct mathematical symbols and models. }\end{array}$ \\
\hline 2 & $\begin{array}{l}\text { Present oral, written, picture and } \\
\text { diagram math statements }\end{array}$ & $\begin{array}{l}\text { Students are not able to explain the ideas } \\
\text { contained in the story problem in their own } \\
\text { words and explain the ideas in writing. } \\
\text { Students are not able to make relevant pictures } \\
\text { with the correct mathematical model. }\end{array}$ \\
\hline 3 & Perform mathematical manipulations & $\begin{array}{l}\text { Students are not able to solve math problems } \\
\text { using the right way or method. }\end{array}$ \\
\hline 4 & $\begin{array}{l}\text { Find patterns or properties of } \\
\text { mathematical phenomena to make } \\
\text { generalizations }\end{array}$ & $\begin{array}{l}\text { Students are unable to find several possible } \\
\text { patterns of the optimum value of the known } \\
\text { optimum function. }\end{array}$ \\
\hline 5 & $\begin{array}{l}\text { Checks the validity of an argument } \\
\text { Students are unable to make cor rect decisions } \\
\text { based on the patterns obtained. }\end{array}$ \\
\hline 6 & $\begin{array}{l}\text { Draw conclusions, compile evidence, } \\
\text { provide reasons or evidence for several } \\
\text { solutions }\end{array}$ & $\begin{array}{l}\text { Students are not able to make conclusions in their } \\
\text { own written language. }\end{array}$ \\
\hline
\end{tabular}




\subsection{Research Findings on Students' Mathematical Communication Ability with}

Almost Correct Answers

The following are the findings of research on students' mathematical communication skills with the criteria of students with almost correct answers in table 6 below.

Table 6. Summary of Research Findings of Students' Mathematical Communication Ability with Almost Correct Answers

\begin{tabular}{|c|l|l|} 
No. & \multicolumn{1}{|c|}{$\begin{array}{c}\text { Mathematical Communication } \\
\text { Ability Indicator }\end{array}$} & \multicolumn{1}{c|}{ Research Findings } \\
\hline 1 & $\begin{array}{l}\text { Using models, diagrams and symbols } \\
\text { to represent a mathematical concept or } \\
\text { idea }\end{array}$ & $\begin{array}{l}\text { Students are not able to represent the problem in } \\
\text { the form of a relatively long s tory problem into } \\
\text { the correct mathematical symbols and models. }\end{array}$ \\
\hline 2 & $\begin{array}{l}\text { Present oral, written, picture and } \\
\text { diagram math statements }\end{array}$ & $\begin{array}{l}\text { Students are not able to explain the ideas } \\
\text { contained in the story problem in their own } \\
\text { words and explain the ideas in writing. } \\
\text { Students are not able to make relevant pictures } \\
\text { with the correct mathematical model. }\end{array}$ \\
\hline 3 & Perform mathematical manipulations & $\begin{array}{l}\text { Students are not able to solve math problems } \\
\text { using the right method or method. }\end{array}$ \\
\hline 4 & $\begin{array}{l}\text { Find patterns or properties of } \\
\text { mathematical phenomena to make } \\
\text { generalizations }\end{array}$ & $\begin{array}{l}\text { Students are unable to find several possible } \\
\text { patterns of the optimum value of the known } \\
\text { optimum function. }\end{array}$ \\
\hline 5 & $\begin{array}{l}\text { Checks the validity of an argument } \\
\text { Students are unable to make correct decisions } \\
\text { based on the patterns obtained. }\end{array}$ \\
\hline 6 & $\begin{array}{l}\text { Draw conclusions, compile evidence, } \\
\text { provide reasons or evidence for several } \\
\text { solutions }\end{array}$ & $\begin{array}{l}\text { Students are not able to make conclusions in their } \\
\text { own written language. }\end{array}$ \\
\hline
\end{tabular}

\subsection{Research Findings of Mathematical Communication Ability in Students With} Many Wrong Answers

The following are the findings of research on students' mathematical communication skills with the criteria of students with many wrong answers in table 7 below.

Table 7. Summary of Research Findings of Students' Mathematical Communication Ability with Many Wrong Answers

\begin{tabular}{|c|l|l|}
\hline No. & \multicolumn{1}{|c|}{$\begin{array}{c}\text { Mathematical Communication } \\
\text { Ability Indicator }\end{array}$} & \multicolumn{1}{c|}{ Research Findings } \\
\hline 1 & $\begin{array}{l}\text { Using models, diagrams and symbols } \\
\text { to represent a mathematical concept or } \\
\text { idea }\end{array}$ & $\begin{array}{l}\text { Students are not able to represent the problem in } \\
\text { the form of a relatively long story problem into } \\
\text { the correct mathematical symbols and models. }\end{array}$ \\
\hline 2 & $\begin{array}{l}\text { Present oral, written, picture and } \\
\text { diagram math statements }\end{array}$ & $\begin{array}{l}\text { Students are not able to explain the ideas } \\
\text { contained in the story problem in their own } \\
\text { words and explain the ideas in writing. } \\
\text { Students are not able to make relevant pictures } \\
\text { with the correct mathematical model. }\end{array}$ \\
\hline 3 & Perform mathematical manipulations & $\begin{array}{l}\text { Students are not able to solve math problems } \\
\text { using the right method or method. }\end{array}$ \\
\hline 4 & $\begin{array}{l}\text { Find patterns or properties of } \\
\text { mathematical phenomena to make } \\
\text { generalizations }\end{array}$ & $\begin{array}{l}\text { Students are unable to find several possible } \\
\text { patterns of the optimum value of the known } \\
\text { optimum function. }\end{array}$ \\
\hline 5 & $\begin{array}{l}\text { Checks the validity of an argument } \\
\text { Students are unable to make correct decisions } \\
\text { based on the patterns obtained. }\end{array}$ \\
\hline 6 & $\begin{array}{l}\text { Draw conclusions, compile evidence, } \\
\text { provide reasons or evidence for several } \\
\text { solutions }\end{array}$ & $\begin{array}{l}\text { Students are not able to make conclusions in their } \\
\text { own written language. }\end{array}$ \\
\hline
\end{tabular}




\subsection{Research Findings of Mathematical Communication Ability in Students with}

Special Cases

From the research data, it was found that the students really needed assistance in learning mathematics. One of them is the peer tutoring technique. The following are the findings of research on students' mathematical communication skills with the criteria of students with special cases in table 8 below.

Table 8. Summary of Research Findings on Students' Mathematical Communication Ability with Special Cases

\begin{tabular}{|c|l|l|}
\hline No. & \multicolumn{1}{|c|}{$\begin{array}{c}\text { Mathematical Communication } \\
\text { Ability Indicator }\end{array}$} & \multicolumn{1}{c|}{ Research Findings } \\
\hline 1 & $\begin{array}{l}\text { Using models, diagrams and symbols } \\
\text { to represent a mathematical concept or } \\
\text { idea }\end{array}$ & $\begin{array}{l}\text { Students are not able to represent the problem in } \\
\text { the form of a relatively long story problem into } \\
\text { the correct mathematical symbols and models. }\end{array}$ \\
\hline 2 & $\begin{array}{l}\text { Present oral, written, picture and } \\
\text { diagram math statements }\end{array}$ & $\begin{array}{l}\text { Students a re not able to explain the ideas } \\
\text { contained in the story problem in their own } \\
\text { words and explain the ideas in writing. } \\
\text { Students are not able to make relevant pictures } \\
\text { with the correct mathematical model. }\end{array}$ \\
\hline 3 & Perform mathematical manipulations & $\begin{array}{l}\text { Students are not able to solve math problems } \\
\text { using the right method or method. }\end{array}$ \\
\hline 4 & $\begin{array}{l}\text { Find patterns or properties of } \\
\text { mathematical phenomena to make } \\
\text { generalizations }\end{array}$ & $\begin{array}{l}\text { Students are unable to find several possible } \\
\text { patterns of the optimum value of the known } \\
\text { optimum function. }\end{array}$ \\
\hline 5 & $\begin{array}{l}\text { Checks the validity of an argument } \\
\text { Students are unable to make correct decisions } \\
\text { based on the patterns obtained. }\end{array}$ \\
\hline 6 & $\begin{array}{l}\text { Draw conclusions, compile evidence, } \\
\text { provide reasons or evidence for several } \\
\text { solutions }\end{array}$ & $\begin{array}{l}\text { Students are not able to make conclusions in their } \\
\text { own written language. }\end{array}$ \\
\hline
\end{tabular}

In general, from the test results of students' mathematical communication skills in the whole research subject can be described based on the indicators of mathematical communication skills in table 9 as follows:

Table 9. Students' Mathematical Communication Ability Test Results Based on Indicators

\begin{tabular}{|c|l|c|c|}
\hline No & Mathematical Communication Ability Indicator & $\begin{array}{c}\text { Student Error } \\
\text { Indicators }\end{array}$ & $\begin{array}{c}\text { Many } \\
\text { Students }\end{array}$ \\
\hline 1 & $\begin{array}{l}\text { Using models, diagrams and symbols to represent a } \\
\text { mathematical concept or idea }\end{array}$ & False Fact & 7 \\
\cline { 2 - 4 } 2 & $\begin{array}{l}\text { Present oral, written, picture and diagram math } \\
\text { statements }\end{array}$ & Concept Error & 15 \\
\hline 3 & Perform mathematical manipulations & Principle Mistakes & 21 \\
\hline 4 & $\begin{array}{l}\text { Find pattern or properties of mathematical } \\
\text { phenomena to make generalizations }\end{array}$ & Principle Mistakes & 25 \\
\hline 5 & Checks the validity of an argument & Principle Mistakes & 25 \\
\hline 6 & $\begin{array}{l}\text { Draw conclusions, compile evidence, provide } \\
\text { reasons or evidence for several solutions }\end{array}$ & 25 \\
\hline
\end{tabular}

4.7 Research Findlings on Students' Attitudes Toward Mathematics Learning in the application of Vygotsky's Theory

To determine students' attitudes towards mathematics in the application of Vygotsky's theory, it was obtained from the data from the student attitude questionnaire. From the data from the student questionnaire, it shows that students' attitudes towards mathematics learning in the application of Vygotsky's theory are positive. This means that students are able to adapt to the mathematics learning applied by researchers in the classroom. 
This positive attitude of students is evidenced by the percentage of students 'attitudes which include students' attitudes towards mathematics learning, students 'attitudes towards the application of Vygotsky's theory in mathematics learning, and students' attitudes towards the questions given. Each attitude showed a significant percentage, respectively $66.98 \%, 72.62 \%$ and $70.86 \%$.

This study focuses on the analysis of students' mathematical communication skills in applying Vygotsky's theory at the high school level. This section will discuss the research findings data from mathematical communication skills and the scale of students' attitudes towards learning in the application of Vygotsky's theory.

\subsection{Analysis of Students' Mathematical Communication Ability Levels}

Mathematical communication skills are one of the abilities that must be possessed and instilled in every student, because this is one of the basic abilities that is in line with the recommendations of the National Council of Teachers of Mathematics (Sinaga, 2012) regarding five fundamental goals in learning mathematics, namely:

1. That they learn to value mathematics;

2. That they become confident in their ability to do mathematics;

3. That they become mathematical problem-solvers;

4. That they learn to communicate mathematically;

5. That they learn to reason mathematically.

Based on the definitions above, the researcher takes several indicators that show that students have mathematical communication skills, including:

a. Students can present mathematical statements orally, in writing, pictures and diagrams.

b. Students can use models, diagrams and symbols to represent mathematical concepts or ideas.

c. Students can perform mathematical manipulations.

d. Students can draw conclusions, compile evidence, provide reasons or evidence for several solutions.

e. Students can check the validity of an argument

f. Students can find patterns or properties of mathematical symptoms to make generalizations.

From the test results of students' mathematical communication skills of class XI MIA 2 at Al Ulum Medan Private High School on the two-variable linear program material with 35 students, it was found that 3 students $(8.33 \%)$ had a high level of mathematical communication skills, 7 students $(19.44 \%)$ have a moderate level of mathematical communication skills, while 25 students $(72.22 \%)$ have a low level of mathematical communication skills. This shows that the majority of students experience problems with mathematical communication skills.

Students' mistakes in communicating mathematically can be seen from the number of students who did not finish answering the story questions based on the indicators of mathematical communication skills that have been described previously. These errors include errors in using mathematical objects, namely facts, operations and principles in mathematics. Errors of mathematical objects in learning are thought to occur because (1) there is a conflict with existing agreements in mathematics, (2) drawing wrong conclusions or generalizations, or (3) wrong operations or procedures.

In addition, the students' low mathematical communication skills are also caused by the fact that students are rarely given contextual questions which are stated in relatively long stories. According to Sinaga (2012) math story questions are a form of questions that originate from real life (contextual) which are presented in short stories. In other words, the story questions are reflected in daily life, both those that are directly related to students and what the students can imagine themselves. The existence of a story problem at the end of the material in mathematics learning is intended so that students know the benefits/uses of the material being studied.

The main obstacle for students in solving story problems, especially in the twovariable linear program material, is that they experience difficulty in understanding the language meaning of the sentences used because the language in the questions needs to be interpreted in the form of variables, mathematical models, arithmetic operations and 
inaccuracies. The majority of students find it difficult to make mathematical models of the constraint function and optimum function of linear programming problems. The difficulty of students in making mathematical models of the constraint function can be seen from the students' mistakes in stating the right sign of inequality to state the constraints that are maximizing and constraints that are minimizing. The difficulty of students in making mathematical models has an impact on the difficulty in determining the area of the set of solutions from linear programs as well as difficulties in making decisions about the optimum value (maximum or minimum).

Therefore, in the future in learning mathematics, especially in the linear program material of two variables, students must be brought closer to contextual questions so that students can feel the benefits of the material being taught. From the data from the student attitude questionnaire that has been given, there is a measurement of students' attitudes towards the questions given. In this study, the researcher used contextual story questions to generate students' mathematical communication skills. From the results of the questionnaire, it appears that the students' attitudes towards the questions given during the learning of the two-variable linear program showed a positive attitude of $70.86 \%$. This means that students prefer to be given contextual questions that lead to material benefits in daily life.

\subsection{Application of Vygotsky's Learning Theory in Teaching and Learning Interaction}

Vygotsky's Theory, or commonly known as Vygotsky's Sociocultural Theory, is a theory of learning that describes learning as a social process and the origin of human intelligence in society or culture. The main point of Vygotsky's theoretical framework is that social interactions play a fundamental role in the development of cognitive aspects.

According to Ebert and Culyer (Botty, 2014), the idea in Vygotsky's learning is an exercise in social interaction because the information obtained comes from other people. Meanwhile Moore (Botty, 2014) sees Vygotsky's idea of learning and teaching as a social activity that basically occurs between social actors built in social situations. Both of these views show that Vygotsky's theory focuses on interactions in the classroom where the teaching and learning process takes place. There is a transfer of knowledge from one individual to another through verbal communication and perhaps also through demonstrations. In class, teachers are expected to be knowledgeable people but other students can also have knowledge and understanding that can help peers who need explanations and more understanding of the subject matter.

Vygotsky's theory offers a portrait of human development as something that is inseparable from social and cultural activities. Vygotsky emphasized how mental development processes such as memory, attention, and reasoning involve learning using societal findings such as language, mathematical systems, and memory tools. He also emphasized how children are helped to develop with guidance from people who are already skilled in these fields. Vygotsky emphasized more on the role of adults and other children in facilitating the child's development.

Scaffolding is a term related to cognitive development that Vygotsky uses to describe changes in support during a learning session, where a more skilled person changes guidance according to the child's ability level. In simple terms, scaffolding learning can be interpreted as a technique of providing structured learning support, which is carried out at an early stage to encourage students to learn independently. The provision of learning support is not carried out continuously, but along with the increase in student abilities, gradually the teacher must reduce and release students to learn independently. If students have not been able to achieve independence in their learning, the teacher returns to the support system to help students make progress until they are truly able to achieve independence.

Scaffolding is more likely to be verbal. Teachers and peers who have competence as facilitators in a scientific approach need to emphasize interaction through language in applying scaffolding. According to Myhill \& Warren (Abduh, 2017) talk as the mediating tool in the construction of knowledge. Meanwhile, Mercer \& Littleton (Abduh, 2017) argue that structured classroom talk between teacher and students guides the construction of knowledge. Thus, language is the main tool in constructing knowledge through 
scaffolding, or in other words the interaction between teachers, peers and students is the main key. The purpose of Vygotsky's view of the use of language in the learning process emphasizes that a form of children's statement is an important part and acts as a concrete action in achieving the expected goals. Children don't just talk about what they do. The statements and actions they take are part of a psychological function that is complex and unified, which leads to problem solving of the problems it faces. Therefore, the use of language as a means of communication in learning is very necessary. The use of appropriate and effective language in learning will help children solve the problems they face.

From the questionnaire data on students 'attitudes towards learning mathematics in the application of Vygotsky's theory, the results showed that students' positive attitudes in learning mathematics in applying Vygotsky's theory were obtained. The percentage of students 'attitudes towards the application of Vygotsky's theory in mathematics learning in class was $72.62 \%$ indicating that the students' attitudes towards the application of Vygotsky's theory in mathematics learning were good. This means that students are able to well accept mathematics learning in the application of Vygotsky's theory to be applied in the classroom. Learning mathematics in the application of Vygotsky's theory which is applied by teachers in the classroom is able to foster students' mathematical communication skills both orally and in writing and make students more independent in solving problems, especially on two-variable linear program material.

\section{Conclusion}

The Based on the results of data analysis and discussion in this study, the following conclusions are stated:

1. Devices There are 3 students $(8.57 \%)$ who have a high level of mathematical communication skills; 7 students $(20 \%)$ have moderate level of mathematical communication skills; 25 students $(71.43 \%)$ have a low level of mathematical communication skills. From the results of the answers on the student answer sheets, it can be described that students with high mathematical communication skills provide answers to each question in a sequence and correctly according to the indicators of mathematical communication skills asked in the questions. Students in this category complete all 4 test questions. For students with moderate mathematical communication skills, they are only able to solve 3 of the 4 test questions. The student provides answers to each question in a sequence according to the indicators of mathematical communication skills asked in the questions. However, there were students who did not answer the questions correctly. For students in the low category, they can only answer a maximum of 2 questions out of the 4 questions given, there are even students who do not write down the answers at all. The answer patterns of students who were able to solve the 2 questions varied, some were able to answer all the questions, some only answered part of the question questions

2. After analyzing the student's answer process descriptively, the student's answer process to the mathematical communication test can be concluded as follows:

a. In the first indicator, namely using models, diagrams and symbols to represent a mathematical concept or idea, it was found that 15 students were able to solve the questions correctly, 13 students were able to solve the questions correctly but there were deficiencies, and 7 students were unable to solve question well.

b. In the second indicator, which is presenting mathematical statements orally, in writing, pictures and diagrams, it was found that 8 students were able to solve the questions correctly, 11 students were able to solve the questions correctly but there were deficiencies, and 16 students were not able to solve the questions properly.

c. In the third indicator, which is performing mathematical manipulation, it was found that 8 students were able to solve the questions correctly, 6 students were able to solve the questions correctly but there were deficiencies, and 21 students were not able to solve the questions properly.

d. In the fourth indicator, which is finding patterns or properties of mathematical 
symptoms to make generalizations, it was found that 4 students were able to solve the questions correctly, 6 students were able to solve the questions correctly but there were deficiencies, and 25 students were not able to solve the questions properly.

e. In the fifth indicator, which is checking the validity of an argument, it was found that 6 students were able to solve the questions correctly, 4 students were able to solve the questions correctly but there were deficiencies, and 25 students were not able to solve the questions properly.

f. In the sixth indicator, namely drawing conclusions, compiling evidence, providing reasons or evidence for several solutions, it was found that 4 students were able to solve the questions correctly, 6 students were able to solve the questions correctly but there were deficiencies, and 25 students were unable to solve the questions correctly. good.

3. After analyzing the students 'errors and difficulties descriptively, the students' mistakes and difficulties in solving the mathematical communication skills test questions can be concluded as follows:

a. In the first indicator, namely using models, diagrams and symbols to represent a mathematical concept or idea, it is concluded that (1) students are unable to represent problems in the form of relatively long story problems into the correct mathematical symbols and models, (2) students still have difficulty solving problems of mathematical communication skills, namely difficulties in indicators of facts and principles. The difficulty of students in expressing facts is because students are rarely given contextual questions that are stated in relatively long stories, especially in understanding the language meaning of the sentences used. Meanwhile, the difficulty of students in expressing principles is due to the lack of students' ability to make relationships between mathematical objects that are interrelated with one another.

b. In the second indicator, which is presenting mathematical statements orally, in writing, pictures and diagrams, it is concluded that (1) students are not able to explain the ideas contained in the story problems in their own words and describe the ideas in writing, (2) students are not able to make images that are relevant to the correct mathematical model, (3) students still have difficulty solving problems of mathematical communication skills on concept indicators. The difficulty of students expressing concepts is caused by the inability of students to express the ideas in their minds in written form.

c. In the third indicator, namely performing mathematical manipulation, it is concluded that (1) students are not able to solve mathematical problems using the right method or method, (2) students still have difficulty solving problems of mathematical communication skills, namely difficulties in operating indicators. The difficulty of students in using proper operations is caused by the inability of students to determine the problem solving procedures used.

d. In the fourth indicator, which is finding patterns or properties of mathematical symptoms to make generalizations, it is concluded that (1) Students are not able to find several possible patterns of the optimum value of the known optimum function, (2) students have difficulty solving problems on mathematical communication skills, namely difficulties. on principle indicators.

e. In the fifth indicator, which is checking the validity of an argument, it is concluded that (1) students are not able to make correct decisions based on the patterns obtained, (2) students have difficulty solving problems on mathematical communication skills, namely difficulties in principle indicators.

f. In the sixth indicator, namely drawing conclusions, compiling evidence, providing reasons or evidence for several solutions, it is concluded that (1) Students are not able to make conclusions in their own written language, (2) students have difficulty solving problems on mathematical communication skills, namely difficulties with indicators principle. 


\section{References}

Abduh, M, 2017. Interaksi Pada Pendekatan Saintifik (Kajian Teori Scaffolding). Seminar Nasional Pendidikan PGSD UMS \& HDPGSDI Wilayah Jawa. ISBN 978-60270471-2-9.

Ansari,B. 2016 , Komunukasi Matematik Strategi Berfikir dan Manajemen Belajar : Konsep dan Aplikasi, Banda Aceh : Yayasan PeNA.

Botty, H. 2014. The Impact of Gagné, Vygotsky and Skinner Theories in Pedagogical Practices of Mathematics Teachers in Brunei Darussalam. Review of European Studies; Vol. 6, No. 4. ISSN 1918-7173.

Fitri, S., \& Zahari, C.L. 2019.-The implementation of blended learning to improve understanding of mathematicsll, The Sixth Seminar Nasional Pendidikan Matematika Universitas Ahmad Dahlan 2018: IOP Conf. Series: Journal of Physics: Conf. Series 1188 (2019) 012109, 2018, doi:10.1088/1742-6596/1188/1/012109.

Fitri, S., Syahputra, E., \& Syahputra, H. 2019. "Blended Learning Rotation Model of Cognitive Conflict Strategy to Improve Mathematical Resilience in High School Students", International Journal of Scientific \& Technology Research, vol.1, no. 1.

Irhamna, Amry, Z., and Syahputra, H. (2020). Contribution of Mathematical Anxiety, Learning Motivation and Self-Confidence to Student's Mathematical Problem Solving. Budapest International Research and Critics in Linguistics and Education (BirLE) Journal Vol 3 (4): 1759-1772.

Kaya, D. 2014. Elementary Mathematics Teachers' Perceptions and Lived Experiences on Mathematical Communication. Eurasia Journal of Mathematics, Science \& Technology Education. ISSN: 1305-8223.

Mahmuzah, R \& Aklimawati. 2016. Pembelajaran Problem Posing untuk Mengembangkan Kemampuan Komunikasi Matematis Siswa SMP. Jurnal Didaktik Matematika; Vol 3, No. 2. ISSN: 2355-4185.

Nasution, Y.S., Syahputra, E., Mulyono. (2020). The Development of Learning Instrument Using Problem Based Learning Model to Improve Critical Thinking of Junior High School Students. Budapest International Research and Critics in Linguistics and Education (BirLE) Journal Vol 3 (3): 1501-1508

Sari, W. 2017. Upaya Meningkatkan Kemampuan Pemecahan Masalah Siswa Kelas VIII-A SMP 2 Nanggulan Dalam Pembelajaran Matematika Pokok Bahasan Bangun Ruang Menggunakan Model Pembelajaran Kooperatif Tipe TPS. Semnastika Unimed. ISBN:978-602-17980-9-6. 6 Mei 2017.

Sinaga, M. I. 2012. Pengaruh Kemampuan Komunikasi Matematika Terhadap Kemampuan Menyelesaikan Soal Cerita Pada Pokok Bahasan Bangun Ruang Sisi Lengkung Siswa Kelas XI SMP Negeri 1 Raya Tahun Pelajaran 2011/2012 Melalui Model Pembelajaran Pemecahan Masalah. Skripsi. Medan : FMIPA UNIMED.

Yang, E. F. Y., Chang, B., Cheng, H. N. H., \& Chan, T. W. (2016). Improving Pupils' Mathematical Communication Abilities Through Computer Supported Reciprocal Peer Tutoring. Educational Technology \& Society, 19 (3), 157-169. 